\title{
Peran Notaris Dalam Membuat Akta Wasiat Yang Bertentangan Dengan Kompilasi Hukum Islam (Studi Akta Notaris Nomor 12 Tanggal 27 Oktober 1984 Tentang Wasiat)
}

\author{
Mohammad Hafid Arkan \\ Fakultas Hukum Univrsitas Islam Indonesia Yogyakarta Indonesia \\ Jln. Cik Di Tiro No. 1 Yogyakarta \\ hafidarkan01@gmail.com
}

\begin{abstract}
This study aims to analyze whether the notary in making deeds must always fulfill the wishes of the client, then analyze the role of the notary in making will deeds based on the provisions of the applicable laws and regulations in Indonesia, and the legal consequences of wills made by notaries who contrary to the prevailing legal system (study of Notary deed No. 12 dated 27 October 1984 on Will). This is an empirical juridical research. The results of the research explain that there is no obligation for the notary to fulfill every wish of the client without first ensuring that the formal and material requirements can be fulfilled by the client, then the role of the notary in making a will before a notary refers to the provisions of Article 1 paragraph (1) of UUJN, and the legal consequence of an authentic will deed made by a Notary who commits an act against the law for his negligence in the deed creation loses the deed's authenticity and becomes a deed under-hand and the authentic deed can be canceled if the arguing party can prove it in court proceedings.
\end{abstract}

Key Words: Legal implications; notary; notary's authorities

\begin{abstract}
Abstrak
Penelitian ini bertujuan untuk menganalisis apakah Notaris dalam pembuatan akta harus selalu memenuhi keinginan penghadap dalam pmbuatan akta, kemudian menganalisa peran Notaris dalam pembuatan akta wasiat berdasarkan ketentuan peraturan perundang-undangan yang berlaku di Indonesia, dan menganalisa akibat hukum dari akta wasiat yang dibuat oleh Notaris yang bertentangan dengan sistem hukum yang berlaku (studi terhadap akta Notaris Nomor 12 Tanggal 27 Oktober 1984 tentang Wasiat). Penelitian ini adalah penelitian yuridis empiris. Hasil penelitian menjelaskan bahwa tidak ada kewajiban bagi Notaris untuk memenuhi setiap keinginan penghadap tanpa terlebih dahulu Notaris memastikan apakah syarat-syarat formil maupun materiil dapat dipenuhi oleh penghadap, kemudian peran Notaris dalam pembuatan wasiat di hadapan seorang Notaris mengacu pada ketentuan Pasal 1 angka 1 UUJN, dan akibat hukum terhadap akta wasiat yang bersifat otentik yang dibuat oleh seorang Notaris yang melakukan perbuatan melawan hukum atas kelalaiannya dalam pembuata akta (isi) adalah hilangnya keotentikan akta tersebut dan menjadi akta di bawah tangan serta akta otentik tersebut dapat dibatalkan apabila pihak yang mendalilkan dapat membuktikannya dalam persidangan di pengadilan.
\end{abstract}

Kata-kata Kunci: Notaris; kewenangan notaris; akibat hukum 


\section{Pendahuluan}

Negara Republik Indonesia sebagai negara hukum berdasarkan Pancasila dan Undang-Undang Dasar Republik Indonesia Tahun 1945 menjamin kepastian, ketertiban, dan perlindungan hukum bagi setiap warga negara. Untuk menjamin kepastian, ketertiban, dan perlindungan hukum dibutuhkan alat bukti tertulis yang bersifat otentik mengenai perbuatan, perjanjian, penetapan, dan peristiwa hukum yang dibuat di hadapan atau oleh pejabat yang berwenang. ${ }^{1}$

Notaris berdasarkan ketentuan Pasal 1 angka 1 Undang-Undang Nomor 2 Tahun 2014 tentang Perubahan Atas Undang-Undang Nomor 30 Tahun 2004 tentang Jabatan Notaris menyebutkan bahwa, "Notaris adalah pejabat umum yang berwenang untuk membuat akta otentik dan memiliki kewenangan lainnya sebagaimana dimaksud dalam undang-undang ini atau berdasarkan undangundang lainnya."2 Sehingga dapat dipahami bahwa Notaris adalah pejabat umum yang secara khusus diberikan wewenang oleh undang-undang untuk membuat suatu alat bukti yang otentik (mempunyai kekuatan pembuktian yang sempurna).

Rumusan atas unsur-unsur Notaris sebagaimana yang terdapat dalam Undang-Undang Nomor 2 Tahun 2014 tentang Perubahan Atas Undang-Undang Nomor 30 Tahun 2004 tentang Jabatan Notaris terdiri dari:

1. Pejabat umum;

2. Mempunyai kewenangan untuk membuat akta otentik;

3. Kewenangan lainnya yang diberikan oleh undang-undang di luar UndangUndang Jabatan Notaris.

Sebagai penegasan tentang kewenangan Notaris dalam pembuatan akta otentik yang diatur di luar Undang-Undang Jabatan Notaris sebagaimana yang terdapat dalam Pasal 1868 KUHPerdata tersebut dinyatakan bahwa, "akta otentik ialah suatu akta yang yang di dalam bentuk yang ditentukan oleh undangundang dibuat oleh atau di hadapan pejabat umum yang berwenang di tempat dimana akta itu dibuat."3

Akta otentik sebagai alat bukti terkuat dan terpenuh mempunyai peranan penting dalam setiap hubungan hukum dalam kehidupan masyarakat. Dalam berbagai hubungan bisnis, kegiatan di bidang perbankan, pertanahan, kegiatan sosial, dan lain-lain. Kebutuhan akan pembuktian tertulis berupa akta otentik

${ }^{1}$ M. Luthfan Hadi Darus, Hukum Notariat dan Tanggungjawab Jabatan Notaris, Cetakan Pertama, UII Press, Yogyakarta, 2017, hlm. 1.

${ }^{2}$ Lihat di dalam Pasal 1 angka 1 Undang-Undang Nomor 2 Tahun 2014 tentang Perubahan Atas UndangUndang Nomor 30 Tahun 2004 tentang Jabatan Notaris.

${ }^{3}$ Lihat di dalam Pasal 1868 Kitab Undang-Undang Hukum Perdata. 
makin meningkat sejalan dengan berkembangnya tuntutan akan kepastian hukum dalam berbagai hubungan ekonomi dan sosial, baik dalam tingkat nasional, regional, maupun global. Melalui akta otentik yang menentukan secara jelas hak dan kewajiban, menjamin kepastian hukum, dan sekaligus diharapkan pula dapat dihindari terjadinya sengketa. Walaupun sengketa tersebut dapat dihindari, dalam proses penyelesaian sengketa tersebut, akta otentik yang merupakan alat bukti tertulis dan terpenuh memberi sumbangan nyata bagi penyelesaian perkara secara murah dan cepat.

Jabatan Notaris diadakan atau kehadirannya dikehendaki oleh aturan hukum dengan maksud untuk membantu dan melayani masyarakat yang membutuhkan alat bukti tertulis yang bersifat otentik mengenai keadaan, peristiwa, atau perbuatan hukum. ${ }^{4}$ Dengan dasar seperti ini mereka yang diangkat sebagai Notaris harus mempunyai semangat untuk melayani masyarakat, dan atas pelayanan tersebut, masyarakat yang telah merasa dilayani oleh Notaris sesuai dengan tugas jabatannya, dapat memberikan honorarium kepada Notaris. ${ }^{5}$ Oleh karena itu Notaris tidak berarti apa-apa jika masyarakat tidak membutuhkannya. Dari pernyataan tersebut hubungan masyarakat dengan Notaris adalah layanan jasa produk hukum.

Kebutuhan akan jasa Notaris dalam masyarakat modern tidak mungkin dihindarkan. Notaris sebagai pejabat umum diangkat oleh pemerintah dan pemerintah sebagai organ negara mengangkat Notaris bukan semata untuk kepentingan Notaris itu sendiri, melainkan juga untuk kepentingan masyarakat luas. Jabatan Notaris merupakan jabatan kepercayaan yang harus selaras dengan mereka yang menjalankan tugas jabatan Notaris sebagai orang yang dipercaya. Notaris sebagai jabatan kepercayaan tidak berarti apa-apa jika ternyata mereka yang menjalankan tugas jabatan sebagai Notaris adalah orang yang tidak dapat dipercaya. Dalam hal ini, antara jabatan Notaris dan pejabatnya (yang menjalankan tugas jabatan Notaris) harus sejalan bagaikan dua sisi mata uang yang tidak dapat dipisahkan. ${ }^{6}$

Jasa yang diberikan oleh Notaris terkait dengan layanan produk hukum tersebut erat dengan persoalan trust (kepercayaan antara para pihak), artinya negara memberikan kepercayaan yang besar terhadap Notaris dan dengan demikian dapat dikatakan bahwa pemberian kepercayaan kepada Notaris. Sebab oleh karenanya Notaris pejabat publik yang mengambil alih peran negara dalam

${ }^{4}$ Habib Adjie, Hukum Notaris Indonesia; Tafsir Tematik Terhadap Undang-Undang Nomor 30 Tahun 2004 Tentang Jabatan Notaris, Cetakan Keempat, PT. Refika Aditama, Bandung, 2014, hlm. 14.

${ }^{5}$ Lihat di dalam Pasal 1868 Kitab Undang-Undang Hukum Perdata.

${ }^{6}$ Habib Adjie, Sanksi Perdata dan Administratif Terbadap Notaris Sebagai Pejabat Publik, Cetakan Kedua, Refika Aditama, Bandung, 2009, hlm. 83. 
melayani masyarakat dalam melayani masyarakat di bidang jasa hukum. Tanggungjawab ini dapat berupa tanggungjawab secara hukum terhadap produk hukum yang dibuatnya maupun secara moral. ${ }^{7}$

Dalam menjalankan tugas jabatannya, Notaris dituntut untuk bertindak secara hati-hati dan profesional. Karena apabila Notaris membuat akta secara tidak benar, dapat dikenakan sanksi yang mengakibatkan suatu akta hanya mempunyai kekuatan pembuktian sebagai akta di bawah tangan atau menjadi batal demi hukum, akibatnya para pihak dapat menuntut penggantian biaya, ganti rugi kepada Notaris tersebut. Terhadap Notaris dapat juga dikenakan sanksi berupa peringatan lisan, tertulis, pemberhentian sementara, pemberhentian dengan hormat atau tidak hormat.

Ruang lingkup pertanggungjawaban Notaris meliputi kebenaran materiil atas akta yang dibuatnya. Mengenai tanggungjawab Notaris selaku pejabat umum yang berhubungan dengan kebenaran materiil, dapat dibedakan menjadi empat, yaitu: ${ }^{8}$

1. Tanggungjawab Notaris secara perdata terhadap kebenaran materiil terhadap akta yang dibuatnya;

2. Tanggungjawab Notaris secara pidana terhadap kebenaran materiil terhadap akta yang dibuatnya;

3. Tanggungjawab Notaris berdasarkan Peraturan Jabatan Notaris terhadap kebenaran materiil terhadap akta yang dibuatnya;

4. Tanggungjawab Notaris dalam menjalankan tugas jabatannya berdasarkan kode etik Notaris.

Salah satu kewenangan Notaris ialah dapat membuat akta wasiat sebagaimana diamanatkan dalam UUJN, termasuk pembuatan wasiat di hadapan saksi-saksi sebagaimana diatur dalam Pasal 939 ayat (4) Kitab Undang-Undang Hukum Perdata dan pembuaatan akta wasiat di luar saksi-saksi sebagaimana diatur dalam Pasal 939 ayat (2) Kitab Undang-Undang Hukum Perdata.

Notaris dalam melakukan suatu tindakan hukum harus senantiasa bertindak secara hati-hati agar Notaris sebelum membuat akta, harus meneliti semua fakta yang relevan dalam pertimbangannya berdasarkan kepada peraturan perundang-undangan yang berlaku. Meneliti semua kelengkapan dan keabsahan alat bukti atau dokumen yang diperlihatkan kepada Notaris, serta mendengar keterangan atau pernyataan para penghadap wajib dilakukan sebagai dasar pertimbangan untuk dituangkan di dalam akta.

${ }^{7}$ Abdul Ghofur Anshori, Lembaga Kenotariatan Indonesia; Perspektif Hukum dan Etika, Cetakan Pertama, Yogyakarta: UII Press, Bandung, 2009, hlm. 43.

${ }^{8}$ Abdul Ghofur Anshori, Op. Cit., hlm. 34. 
Dalam praktiknya, pembuatan akta wasiat oleh Notaris harus memperhatikan segala ketentuan-ketentuan yang diatur atau ditentukan di dalam ketentuan perundang-undangan yang mengatur tentang pelaksanaan wasiat. Sehingga dikemudian hari tidak terjadi sesuatu hal yang dapat merugikan para pihak yang kemudian dapat pula merugikan Notaris yang membuat akta wasiat tersebut.

Berkaitan dengan tugas dan tanggungjawab Notaris, Peneliti tertarik untuk melakukan penelitian terhadap Akta Wasiat Nomor 12 Tanggal 27 Oktober 1984 yang dibuat oleh Pitoyo Kusumo, Notaris yang berkedudukan di Kabupaten Nganjuk yang dikemudian hari digugat karena ada indikasi kelalaian Notaris. Sehingga Penulis mengangkat judul penelitian, yakni Peran Notaris Dalam Membuat Akta Wasiat yang Bertentangan Dengan Ketentuan Kompilasi Hukum Islam (Studi Akta Notaris Nomor 12 Tanggal 27 Oktober 1984 tentang Wasiat).

\section{Rumusan Masalah}

Berdasarkan uraian dalam latar belakang di atas, selanjutnya dapat dirumuskan permasalahan sebagai berikut: pertama, apakah Notaris dalam pembuatan akta harus selalu memenuhi keinginan penghadap dalam pembuatan akta otentik? Kedua, bagaimana peran Notaris dalam pembuatan akta wasiat berdasarkan ketentuan peraturan perundang-undangan yang berlaku di Indonesia? Ketiga, bagaimana akibat hukum dari akta wasiat yang dibuat oleh Notaris yang bertentangan dengan sistem hukum yang berlaku (studi terhadap akta Notaris Nomor 12 Tanggal 27 Oktober 1984 tentang Wasiat)?

\section{Tujuan Penelitian}

Bertitik tolak dari rumusan masalah di atas, maka tujuan dari penelitian ini secara umum adalah untuk menemukan jawaban atas permasalahan yang ada tersebut. Tujuan penelitian dalam penulisan tesis ini adalah: pertama, menganalisa apakah Notaris dalam pembuatan akta harus selalu memenuhi keinginan penghadap dalam pmbuatan akta. Kedua, menganalisa peran Notaris dalam pembuatan akta wasiat berdasarkan ketentuan peraturan perundang-undangan yang berlaku di Indonesia. Ketiga, menganalisa akibat hukum dari akta wasiat yang dibuat oleh Notaris yang bertentangan dengan sistem hukum yang berlaku (studi terhadap akta Notaris Nomor 12 Tanggal 27 Oktober 1984 tentang Wasiat).

\section{Metode Penelitian}

Penelitian dengan judul "Peran Notaris Dalam Membuat Akta Wasiat yang Bertentangan Dengan Ketentuan Kompilasi Hukum Islam (Studi Akta Notaris 
Nomor 12 Tanggal 27 Oktober 1984 tentang Wasiat) adalah merupakan penelitian yuridis empiris, yaitu penelitian hukum mengenai pemberlakuan atau implementasi ketentuan hukum normatif secara perilaku nyata pada setiap peristiwa hukum yang terjadi dalam masyarakat.

Data yang digunakan dalam penelitian ini, berupa data primer dan data sekunder. Data primer adalah data yang diperoleh dari hasil penelusuran kepustakaan terhadap berbagai litratur atau bahan pustaka yang berkaitan dengan masalah atau materi penelitian yang sering disebut sebagai bahan hukum. Sedangkan data sekunder adalah data yang diperoleh dengan cara langsung dari sumber di lapangan melalui penelitian.

Metode pendekatan yang digunakan dalam membahas masalah penelitian ini adalah Metode pendekatan yang digunakan dalam membahas masalah penelitian ini adalah metode pendekatan kasus dan pendekatan perundangundangan (statute approach) dilakukan dengan menelaah semua undang-undang dan regulasi yang bersangkut paut dengan isu hukum yang sedang ditangani. ${ }^{9}$

\section{Hasil Penelitian dan Pembahasan}

\section{Kewajiban Notaris untuk Memenuhi Keinginan Penghadap dalam Pembuatan Akta Otentik}

Notaris dalam menjalankan tugas dan jabatannya dalam membuat akta tidak luput dari kesalahan atau kekeliruan baik yang disebabkan karena perilaku yang tidak profesional atau memihak salah satu pihak sehingga terjadi permasalahan dalam akta yang dibuatnya. Sebagai pejabat umum yang berwenang untuk membuat akta otentik, Notaris seringkali bertindak tidak hatihati yang berakibat menimbulkan permasalahan hukum, baik dalam ranah hukum pidana maupun ranah hukum perdata, ini disebabkan karena pihak yang membuat akta otentik memberikan dokumen palsu ataupun memberikan keterangan palsu kepada Notaris ataupun Notaris yang bersangkutan dengan sengaja bersama-sama dengan penghadap melakukan suatu perbuatan melawan hukum sehingga menimbulkan permasalahan hukum terhadap akta otentik yang dibuatnya.

Seseorang Notaris dipandang sebagai seorang figure yang keteranganketerangannya dapat diandalkan dan dapat dipercayai yang tanda tangannya serta segel (capnya) memberi jaminan dan bukti kuat dalam akta otentik yang dibuatnya. Namun pada saat ini sering terjadi permasalahan hukum dalam hlm. 133.

9Peter Mahmud Marzuki, Penelitian Hukum, Cetakan Keduabelas, Prenadamedia Group, Jakarta, 2016, 
pembuatan akta yang dibuat oleh Notaris, hal ini terkait dengan penghadap yang memberikan dokumen palsu ataupun memberikan keterangan palsu kepada Notaris, sehingga akta yang dibuatnya terindikasi mengandung unsur-unsur pidana karena pihak-pihak yang menghadap dalam proses pembuatan akta memberikan dokumen-dokumen atau surat palsu serta mencantumkan keterangan palsu. Kemudian dari hal tersebut maka timbul pertanyaan, apakah ada kewajiban bagi Notaris untuk memenuhi setiap keinginan penghadap dalam pembuatan akta otentik mengingat adanya kemungkinan pemberian dokumen atau keterangan palsu dari penghadap kepada Notaris yang dijadikan acuan dalam pembuatan akta otentik.

Dalam ketenuan Undang-Undang Jabatan Notaris sebenarnya diatur mengenai hak Notaris untuk menolak memberikan jasa pelayanan hukum kepada penghadap, yang diatur dalam ketentuan Pasal 16 ayat (1) huruf e UndangUndang Nomor 2 Tahun 2014 tentang Perubahan Atas Undanng-Undang Nomor 30 Tahun 2004 tentang Jabatan Notaris (UUJN) meyebutkan bahwa, dalam menjalankan jabatannya Notaris wajib memberikan pelayanan sesuai dengan ketentuan dalam undang-undang ini, kecuali ada alasan untuk menolaknya. Penjelasan terkait alasan menolak ialah alasan yang mengakibatkan Notaris tidak berpihak, seperti adanya hubungan darah atau semenda dengan Notaris sendiri atau dengan suami/istrinya, salah satu pihak tidak mempunyai kemampuan bertindak untuk melakukan perbuatan, atau hal lain yang tidak dibolehkan oleh undang-undang.

Untuk dapat memberikan pelayanan hukum terhadap setiap penghadap yang datang kepada Notaris, maka bagi Notaris perlu untuk memperhatikan dan melaksanakan hal-hal sebagai berikut: 10

1. Melakukan pengenalan terhadap identitas penghadap. Dalam menjalankan tugasnya Notaris sebelum memulai membuat akta tentunya dihadapkan oleh para pihak yang ingin membuat akta otentik, Notaris harus mengecek identitas pihak-pihak seperti KTP, KK, atau pasport serta mencocokkan foto pemilik identitas dengan pihak pihak yang membuat akta otentik,agar mencegah pemalsuan identitas terhadap akta yang dibuat Notaris.

2. Memverifikasi secara cermat data subjek dan objek penghadap. Maksud dan tujuan memverifikasi adalah memeriksa data data subjek dari para pihak, apakah berwenang dan cakap atau tidak dalam melakukan perbuatan hukum sehingga dapat memenuhi syarat sahnya dari suatu akta seperti, apakah pihak yang bertindak sudah berumur minimal 18 (delapan belas) tahun atau telah menikah menurut Pasal 39 ayat (1) huruf a UUJN. Sedangkan bagian dari proses validasi data objek adalah merupakan bagian proses dalam memeriksa dokumen dokumen objek yang dibawa 
oleh penghadap, yang contohnya memeriksa sertifikat kepada Badan Pertanahan Nasional apakah sertifikat tersebut sertifikat asli atau palsu atau memang benar atau tidak yang bersangkutan (penghadap) yang memiliki sertifikat tersebut.

3. Memberikan tenggang waktu dalam pengerjaan akta otentik. Dalam mengerjakan suatu akta agar menghasilkan akta yang baik sepatutnya Notaris memberikan tenggang waktu dalam proses pembuatan akta agar tidak terburu-buru dan dapat bekerja secara cermat serta teliti sehingga tidak menimbulkan kesalahan dalam pengerjaan akta Notaris.

4. Bertindak hati-hati, cermat dan teliti dalam proses pembuatan akta. Bertindak hati-hati cermat dan teliti dalam proses pembuatan akta katakata yang dituangkan ke dalam akta karena dalam pelaksanaannya sangat sering terjadi akta yang dibuat Notaris sering dipermasalahkan karena kata-kata yang dibuat tidak jelas atau menimbulkan penafsiran.

5. Memenuhi segala syarat teknik pembuatan akta Notaris. Untuk membuat akta notariil yang jauh dari indikasi permasalahan hukum, tentunya Notaris harus memenuhi syarat formal dan syarat materiil dari pembuatan akta Notaris berdasarkan Undang-Undang Jabatan Notaris (UUJN). ketentuan mengenai syarat formal dalam pembuatan akta diatur dalam Pasal 38 UUJN. Sedangkan syarat materiil yang harus dipenuhi dalam pembuatan akta otentik diatur dalam Pasal 1320 KUHPerdata.

6. Melaporkan kepada pihak yang berwajib apabila terjadi indikasi pencucian uang dalam transaksi di Notaris. Pada saat ini seringkali terjadi bahwa salah satu tindak pidana pencucian uang yang berasal dari tindak pidana korupsi oleh koruptor seringkali memanfaatkan Notaris melalui bidang real estate berupa jual beli tanah maupun bangunan. Contoh saja kasus pencucian yang dilakukan oleh mantan Kepala Korps Lalu Lintas Polri, Inspektur Jenderal Djoko Susilo yang melibatkan beberapa Notaris/PPAT di Jakarta dan beberapa daerah lainnya yang kemudian diperiksa oleh Komisi Pemberantasan Korupsi (KPK). ${ }^{11}$

Hal yang demikian dapat dikatakan juga sebagai suatu tindakan atau penerapan prinsip kehati-hatian oleh Notaris, seperti yang tertuang dalam ketentuan Pasal 16 ayat (1) huruf a UUJN, yang menyebutkan "dalam menjalankan jabatannya, Notaris wajib bertindak amanah, jujur, saksama, mandiri, tidak berpihak, dan menjaga kepentingan pihak yang terkait dalam perbuatan hukum. Notaris juga perlu utnuk menegakkandan menerapkan spirit yang tertuang dalam ketentuan Pasal 3 ayat (2) Kode Etik Ikatan Notaris yang menyebutkan bahwa, "Notaris dan orang lain yang memangku dan menjalankan

${ }^{11}$ https://www.hukumonline.com/berita/baca/lt51e370a2338ed/peran-notaris-dalam-kasus-djokosusilo/, Akses 1 April 2020. 
jabatan Notaris wajib menghormati dan menjunjung tinggi harkat dan martabat jabatan Notaris".

Apabila dikaitkan dengan proses pembuatan akta wasiat yang diajukan oleh penghadap kepada Notaris, sudah tentu tidak ada kewajiban bagi Notaris untuk memenuhi setiap keinginan penghadap tanpa terlebih dahulu Notaris memastikan apakah syarat-syarat formil maupun materiil dapat dipenuhi oleh penghadap. Berdasarkan hasil penelitian Penulis, bahwa diperlukan kecermatan dan pemahaman hukum bagi Notaris sebelum memutuskan untuk memenuhi keinginan penghadap dalam pembuatan akta wasiat.

Langkah pertama yang perlu diperhatikan oleh Notaris ialah memastikan agama dari pemberi wasiat, apabila pemberi wasiat penganut agama Islam maka Notaris harus juga mengacu pada ketentuan Kompilasi Hukum Islam. Apabila pemberi wasiat membuat wasiat yang tidak sesuai dengan ketentuan yang berlaku maka Notaris wajib untuk menolak keinginan pemberi wasiat tersebut namun Notaris juga diwajibkan untuk memberikan nasihat atau penyuluhan hukum (legal advice) kepada pemberi wasiat tersebut tidak serta merta menolak penghadap yang datang kepada Notaris. ${ }^{12}$

\section{Peran Notaris dalam Pembuatan Akta Wasiat Berdasarkan Ketentuan Peraturan Perundang-undangan yang Berlaku di Indonesia}

Pembuatan wasiat atau testamen adalah merupakan suatu tindakan yang sangat pribadi, hal ini berarti bahwa tindakan itu tidak dapat dilakukan oleh seorang wakil, baik wakil berdasarkan undang-undang maupun wakil berdasarkan kontrak. Lain halnya dalam mengikat perkawinan dan membuat syarat-syarat perkawinan dapat dilakukan oleh seorang wakil, tetapi membuat wasiat harus pewaris sendiri, hal tersebut juga berlaku dalam hal pembuatan surat wasiat, harus pewaris sendiri. Hal yang demikian juga berlaku dalam hal pembuatan wasiat di muka seorang Notaris.

Sebelum membuat akta wasiat, tindakan Notaris terlebih dahulu melakukan pengenalan terhadap si penghadap. Ketika melakukan pengenalan, Notaris harus benar-benar dapat memastikan bahwa penghadap dalam keadaan sehat dan mampu melakukan perbuatan hukum, kemudian menanyakan dan mencermati keinginan si penghadap. Notaris dapat terlebih dahulu menerangkan apa itu wasiat dan bagaimana cara pemberian wasiat, agar si penghadap benar-benar mengerti dan memahami apa yang akan dikehendaki si penghadap. Kemudian Notaris memeriksa bukti surat/objek yang akan diberikan benar atau tidak secara

${ }^{12}$ Hasil wawancara dengan Dyah Maryulina Budi Mumpuni, Notaris/PPAT Kota Yogyakarta dan Anggota Majelis Pengawas Notaris Kota Yogyakarta, 2 Maret 2020. 
terperinci mengenai adanya objek tersebut dan memastikan bahwa sudah pernah/ada atau tidak dibuat sebelumnya terhadap objek yang sesuai dengan keinginan si penghadap, juga melakukan pembacaan dan penandatanganan akta.

Pada testamen tertulis (olographis testament), apabila seseorang masih hidup membuat surat wasiat dan diserahkan kepada Notaris, maka Notaris wajib menyimpan terlebih dahulu akta wasiat (testament acte) tersebut. Untuk melakukan pemberitahuan akta wasiat (testament acte), diharuskan memenuhi syarat yaitu harus sesuai dengan kolom yang diberikan oleh Daftar Pusat Wasiat (DPW). Jika tidak diisi 1 (satu) kolom saja, maka artinya akan kabur. Pencabutan akta wasiat (testament acte) juga harus dilaporkan kepada Daftar Pusat Wasiat (DPW) karena apabila seseorang membuat surat wasiat lagi tanpa mencabut surat wasiat yang terdahulu, maka surat wasiat yang berlaku adalah surat wasiat yang terdahulu.

Selain itu, Notaris juga berkewajiban untuk melaporkan atau memberitahukan wasiat seseorang pada 5 hari minggu pertama setiap bulannya. Jika tidak melaporkannya, maka akta tersebut tidak berlaku sebagai akta otentik, atau dengan kata lain akta tersebut hanya berlaku sebagai akta dibawah tangan, bahkan dapat dinyatakan batal demi hukum. Hal ini sesuai dengan ketentuan dalam Pasal 84 dan Pasal 85 UUJN.

Tentang kewarisan secara umum diatur dalam Pasal 830 Kitab UndangUndang Hukum Perdata yang menyatakan pewarisan terjadi karena kematian. Seperti yang telah kita diketahui, bahwa pengertian hukum waris ialah hukum yang mengatur tentang peralihan harta kekayaan yang ditinggalkan seseorang yang meninggal serta akibatnya bagi para ahli warisnya. ${ }^{13}$ Kitab Undang-Undang Hukum Perdata sendiri memandang hak mewaris sebagai hak kebendaan atas harta kekayaan dari orang yang meninggal dunia. ${ }^{14}$ Adapun mengenai pengertian dari testamen menurut Pasal 875 KUHPerdata ialah, "suatu akta yang memuat pernyataan seseorang tentang apa yang dikehendakinya akan terjadi setelah ia meninggal dunia, dan olehnya dapat dicabut kembali lagi."

Dengan demikian, formalitas-formalitas yang harus diperhatikan dalam proses pembuatan akta wasiat secara umum adalah: 15

1. Kehendak terakhir, yang diberitahukan oleh si pembuat wasiat secara lugas kepada seorang Notaris, harus ditulis oleh Notaris itu dengan katakata yang jelas. Penyampaian ini harus dilakukan sendiri oleh si pembuat wasiat, tidak dapat dilakukan melalui penuturan orang lain, anggota

${ }^{13}$ Efendi Perangin, Hukum Waris, Raja Grafindo, Jakarta, 2001, hlm. 31.

${ }^{14}$ Lihat di dalam Pasal 528 Kitab Undang-Undang Hukum Perdata.

${ }^{15}$ Hasil wawancara dengan Nur Hidayat, Notaris/PPAT Kabupaten Nganjuk, 25 Februari 2020. 
keluarga, atau seorang juru bicara. Jika si pembuat wasiat memberitahukannya di luar hadirnya saksi-saksi, maka setelah kerangka wasiat itu disiapkan oleh Notaris, si pembuat wasiat harus mengulangi kehendak terakhirnya secara lugas kepada Notaris di hadapan saksi-saksi. Si pembuat wasiat tidak mengetahui aturan ini sehingga dalam praktiknya, Notarislah yang membacakannya dan menanyakan apakah apakah yang dibacakan itu benar-benar kehendaknya (pertanyaan ini dilakukan oleh Notaris ang bersangkutan, yaitu pada permulaan sewaktu pembuat wasiat datang untuk menandatangani dan kedua kali setelah seluruh akta dibacakan oleh Notaris.

2. Dengan dihadiri oleh saksi-saksi. Notaris sendiri harus membacakan akta kepada si pembuat wasiat dan setelah pembacaan itu, Notaris harus bertanya kepadanya apakah akta yang dibacakan itu benar mengandung wasiatnya.

3. Akta itu harus ditandatangani oleh si pembuat wasiat, Notaris, dan saksisaksi. Hal ini sesuai dengan ketentuam yang terdapat dalam Pasal 939 KUHPerdata.

4. Jika si pembuat wasiat menerangkan tidak dapat menandatangani atau berhalangan menandatangani akta itu, keterangan si pembuat wasiat serta halangan yang dikemukakan harus ditulis secara tegas dalam akta oleh Notaris yang bersangkutan. ${ }^{16}$

5. Bahasa yang ditulis dalam akta wasiat harus sama dengan bahasa yang dipakai oleh si pembuat wasiat saat menyebutkan kehendak terakhirnya.

6. Setelah surat wasiat tersebut dibuat, maka setiap Notaris dalam tempo 5 hari tiap-tiap bulan wajib melaporkan atas akta wasiat yang dibuat olehnya kepada Daftar Pusat Wasiat (DPW) di Departemen Hukum dan Hak Asasi Manusia. Selain itu, dapat dijelaskan pula mengenai tatacara untuk memenuhi pembuatan akta wasiat, yaitu:

a. Tatacara Testamen Terbuka atau Umum (Openbare Testament)

Si pembuat wasiat menghadap kepada Notaris untuk menyatakan kehendaknya tanpa hadirnya saksi-saksi. Kemudian Notaris mengkonsep atau merancang kehendak si pembuat wasiat tersebut pada sebuah kertas. Setelah itu, si pembuat wasiat kembali menyatakan kehendaknya di hadapan Notaris dan saksi-saksi. Kemudian, Notaris membacakan wasiat tersebut dan menanyakan pada si pembuat wasiat apakah benar rancangan tersebut merupakan kehendak terakhirnya. Pembacaan, pertanyaan, dan jawaban-jawaban tersebut dilakukan juga di hadapan saksi-saksi.

b. Tatacara Testamen Tertulis (Olographis Testament) dan Tatacara Testamen Rahasia

Surat wasiat dari si pembuat wasiat diberikan kepada Notaris untuk disimpan. Penyimpanan tersebut dibuatkan akta penyerahan (acte van 
depot). Jika si pembuat wasiat meninggal dunia, maka Notaris menyerahkan surat wasiat (testament) tersebut kepada Balai Harta Peninggalan (BHP) dan kemudian Balai Harta Peninggalan (BHP) tersebut membuka, membaca, dan menyerahkan kembali kepada Notaris yang bersangkutan. Oleh karena itu, Balai Harta Peninggalan (BHP) membuat 3 berita acara, yaitu:

1) Berita Acara Penyerahan;

2) Berita Acara Pembukaan dan Pembacaan Surat Wasiat;

3) Berita Acara Penyerahan Kembali Surat Wasiat kepada Notaris yang bersangkutan. Selain itu, Notaris dengan syarat yang sama wajib mengirimkan secara tercatat kepada Balai Harta Peninggalan (BHP), yang daerah hukumnya tempat Notaris berada.

\section{Akibat Hukum dari Akta Wasiat yang Dibuat oleh Notaris yang Bertentangan dengan Sistem Hukum yang Berlaku (Studi terhadap Akta Notaris Nomor 12 Tanggal 27 Oktober 1984 tentang Wasiat)}

Terhadap akta wasiat (testament acte) yang dibuat di hadapannya, Notaris bertanggungjawab membacakannya di hadapan saksi-saksi. Setelah itu Notaris memberitahukan akta wasiat (testament acte) tersebut kepada Seksi Daftar Pusat Wasiat, Direktorat Perdata, Direktorat Jenderal Administrasi Hukum Umum, Departemen Hukum dan Hak Asasi Manusia dan kepada Balai Harta Peninggalan (BHP). Sehingga tanggungjawab Notaris berakhir dengan dilakukannya pemberitahuan akta wasiat (testament acte).

Namun, apabila terjadi kesalahan dalam pembuatan akta wasiat (testament acte) dan kesalahan tersebut merupakan kesalahan Notaris, maka Notaris tersebut wajib mempertanggungjawabkannya di muka pengadilan. Dalam hal terjadi kesalahan tersebut, Daftar Pusat Wasiat (DPW) dan Balai Harta Peninggalan (BHP) tidak ikut bertanggungjawab karena Daftar Pusat Wasiat (DPW) dan Balai Harta Peninggalan (BHP) sifatnya hanya menerima laporan-laporan dari Notaris mengenai surat wasiat (testament acte). Kalau dimungkinkan, Notaris memberitahukan pada para ahli waris jika terdapat suatu wasiat atau testament, namun di dalam praktiknya, Notaris kadang-kadang tidak mengetahui kapan pembuat wasiat meninggal dunia, dan dimana alamat atau domisili dari si pembuat wasiat.

Kewajiban Notaris untuk dapat mengetahui peraturan hukum yang berlaku di negara Indonesia juga serta mengetahui hukum apa yang berlaku terhadap para pihak yang datang kepada Notaris untuk membuat akta. Hal tersebut sangat penting agar akta yang dibuat oleh Notaris tersebut memiliki otensitasnya sebagai akta otentik karena sebagai alat bukti yang sempurna, demikian juga 
dalam hal akta wasiat yang dibuat oleh Notaris. Namun dapat saja Notaris melakukan suatu kesalahan dalam pembuatan akta. Kesalahan-kesalahan yang terjadi yaitu:

a. Kesalahan ketik pada salinan Notaris, dalam hal ini kesalahan tersebut dapat diperbaiki dengan membuat salinan baru yang sama dengan yang asli dan hanya salinan yang sama dengan yang asli yang mempunyai kekuatan sama seperti akta asli.

b. Kesalahan bentuk akta Notaris, dalam hal ini dimana seharusnya dibuat berita acara rapat tetapi oleh Notaris dibuat sebagai pernyataan keputusan rapat.

c. Kesalahan isi akta Notaris, dalam hal ini mengenai keterangan dari para pihak yang menghadap Notaris, dimana saat pembuatan akta dianggap benar tapi ternyata kemudian tidak benar. ${ }^{17}$

Akibat hukum terhadap akta wasiat yang bersifat otentik yang dibuat oleh seorang Notaris yang melakukan perbuatan melawan hukum atas kelalaiannya dalam pembuata akta (isi) adalah hilangnya keotentikan akta tersebut dan menjadi akta di bawah tangan serta akta otentik tersebut dapat dibatalkan apabila pihak yang mendalilkan dapat membuktikannya dalam persidangan di pengadilan, karena pembuatan suatu akta otentik harus memuat unsur lahiriah, formil, dan materiil, atau salah satu unsur tersebut tidak benar dan menimbulkan perkara pidana atau perdata yang kemudian dapat dibuktikan ketidakbenarannya. Sehingga dalam menjalankan tugas jabatannya, Notaris harus tunduk pada ketentuan undang-undang dan akta tersebut dibuat oleh dan di hadapan Notaris sesuai dengan prosedur dan tata cara pembuatan akta otentik agar keotentikannya tidak menjadi akta di bawah tangan atau akta tidak sampai dibatalkan. ${ }^{18}$

Dalam hal suatu akta wasiat yang dibuat oleh Notaris dibatalkan oleh putusan hakim di pengadilan, maka jika menimbulkan kerugian bagi para pihak yang berkepentingan, Notaris dapat dituntut untuk memberikan ganti rugi, sepanjang hal tersebut terjadi disebabkan oleh karena kesalahan Notaris. Namun dalam hal pembatalan akta wasiat yang dibuat Notaris oleh pengadilan dengan alasan bukan merupakan kesalahan Notaris, maka para pihak yang berkepentingan tidak dapat menuntut Notaris memberikan ganti rugi.

17Pipin Syarifin, Pengantar Ilmu Hukum, Pustaka Setia, Bandung, 1999, hlm. 71. Honggo Hartono, "Roles of Notary in Drawing Up Marriage Agreement After Constitutional Court Decision Number 69/PuuXiii/2015”, Prophetic Law Review, Vol.2., No.2, 2020, hlm.186.

${ }^{18}$ Habib Adjie, Kebatalan Dan Pembatalan Akta Notaris, Cetakan Ketiga, PT. Refika Aditama, Bandung, 2015, hlm. 32. 
Akta Wasiat Nomor 12, 27 Oktober 1984 yang dibuat oleh Pitoyo Kusumo, Notaris yang berkedudukan di Kabupaten Nganjuk yang digugat oleh suadara kandung si pemberi wasiat. Dalam isi akta tersebut, pemberi wasiat yang beragama Islam, melimpahkan semua warisannya kepada anak angkatnya, dimana hal tersebut membuat ahli waris dari pemberi wasiat dalam hal ini saudara kandung melakukan gugatan ke pengadilan. Dalam ketentuan Pasal 195 ayat (2) meneyebutkan, "wasiat hanya diperbolehkan sebanyak-banyaknya sepertiga dari harta warisan kecuali apabila semua ahli waris menyetujui."

Sri Mulyani Sutiagung selaku Majelis Pengawas Notaris Kabupaten Nganjuk mengatakan bahwa, tugas Majelis Pengawas Notaris dalam hal ada gugatan terkait produk Notaris ialah menerima laporan atau aduan dari masyarakat kemudian memanggil Notaris yang bersangkutan, juga memanggil pihak yang melaporkan. Apabila terbukti dan telah ada putusan persidangan bahwa Notaris tersebut melanggar, maka Notaris dapat diberikan sanksi dari Majelis Pengawas Notaris. Terkait dengan gugatan yang terjadi terhadap Akta Wasiat Nomor 12, 27 Oktober 1984 yang dibuat oleh Pitoyo Kusumo, Sri Mulyani Sutiagung selaku Majelis Pengawas Notaris Kabupaten Nganjuk mempersilahkan bagi pihak-pihak yang merasa dirugikan untuk membuat laporan kepada pihak berwajib untuk selanjutnya dapat diproses seusai denga aturan hukum yang berlaku. Mengingat Notaris yang membuat akta tersebut telah meninggal dunia, maka gugatan kepada Notaris tidak dapat dilakukan. ${ }^{19}$

Terkait adanya pemberian wasiat yang melebihi legitime portie, Agus Triyanta berpendapat bahwa setiap perbuatan hukum terkait pemberian wasiat bagi warga negara Indonesia yang menganut agama Islam maka wajib tunduk dan patuh terhadap ketentuan Kompilasi Hukum Islam (KHI). Sebab KHI merupakan satu-satunya hukum formal (hukum positif) yang mendapat legalitas, hanya saja KHI tidak berdampak pada pemberian sanksi pidana karena KHI bersumber dari Inpres bukan undang-undang, tetapi tetap mengikat terkait sah tidaknya suatu transaksi atau haram-halalnya suatu tindakan. Oleh sebab itu, pihak-pihak yang terkait dengan suatu pemberian wasiat maka wajib patuh dan tunduk terhadap ketentuan yang diatur dalam ketentuan KHI. Terkait kewenangan lembaga yang berwenang untuk mengadili hal tersebut ialah ada pada Pengadilan Agama di mana perbuatan hukum tersebut terjadi. ${ }^{20}$

${ }^{19}$ Hasil wawancara dengan Sri Mulyani Sutiagung, Notaris/PPAT Kabupaten Nganjuk dan Anggota Majelis Pengawas Notaris Kabupaten Jombang, 25 Februari 2020.

${ }^{20}$ Hasil wawancara dengan Agus Triyanta, Akademisi Universitas Islam Indonesia, 11 Maret 2020. 


\section{Penutup}

Tidak ada kewajiban bagi Notaris untuk memenuhi setiap keinginan penghadap tanpa terlebih dahulu Notaris memastikan apakah syarat-syarat formil maupun materiil dapat dipenuhi oleh penghadap. Diperlukan kecermatan dan pemahaman hukum bagi Notaris sebelum memutuskan untuk memenuhi keinginan penghadap dalam pembuatan akta wasiat. Apabila pemberi wasiat membuat wasiat yang tidak sesuai dengan ketentuan yang berlaku maka Notaris wajib untuk menolak keinginan pemberi wasiat tersebut namun Notaris juga diwajibkan untuk memberikan nasihat atau penyuluhan hukum (legal advice) kepada pemberi wasiat tersebut tidak serta merta menolak penghadap yang datang kepada Notaris.

Peran Notaris dalam pembuatan wasiat di hadapan seorang Notaris mengacu pada ketentuan Pasal 1 angka 1 UUJN yang menyebutkan, "Notaris adalah pejabat umum yang berwenang untuk membuat akta otentik dan memiliki kewenangan lainnya sebagaimana dimaksud dalam undang-undang ini atau berdasarkan undang-undang lainnya", dimana tiap surat wasiat atau testamen tersebut harus berbentuk akta guna mendapatkan kepastian hukum sebagai akta otentik yang mengikat. Dengan adanya pembuatan testamen tersebut maka para pihak dapat mengerti dan dapat mengetahui dasar akibat perbuatannya itu dapat diatur sedemikian rupa sehingga kepentingan yang bersangkutan mendapat perlindungan yang wajar sebagaimana diketahui oleh Notaris.

Akibat hukum terhadap akta wasiat yang bersifat otentik yang dibuat oleh seorang Notaris yang melakukan perbuatan melawan hukum atas kelalaiannya dalam pembuata akta (isi) adalah hilangnya keotentikan akta tersebut dan menjadi akta di bawah tangan serta akta otentik tersebut dapat dibatalkan apabila pihak yang mendalilkan dapat membuktikannya dalam persidangan di pengadilan, karena pembuatan suatu akta otentik harus memuat unsur lahiriah, formil, dan materiil, atau salah satu unsur tersebut tidak benar dan menimbulkan perkara pidana atau perdata yang kemudian dapat dibuktikan ketidakbenarannya.

Dalam menjalankan tugas jabatan sebagai Notaris, sudah menjadi kewajiban untuk wajib menerapkan prinsip kehati-hatian agar terhindar dari permasalahan hukum di kemudian hari, salah satunya dengan melakukan pengenalan terhadap identitas penghadap, memverifikasi secara cermat data subjek dan objek penghadap, memberikan tenggang waktu dalam pengerjaan akta otentik, bertindak hati-hati, cermat dan teliti dalam proses pembuatan akta, memenuhi segala syarat teknik pembuatan akta Notaris, serta melaporkan kepada pihak yang berwajib apabila terjadi hal-hal bertentangan dengan peraturan hukum. 
Notaris yang memberikan pelayanan terhadap masyarakat yang ingin membuat akta wasiat harus memperhatikan dan menerapkan aturan yang berlaku agar dapat menjamin kepentingan para pihak. Oleh sebab itu, Notaris juga wajib untuk terus meningkatkan kemampuan dalam menganalisa dan memberikan jasa pelayanan hukum kepada masyarakat yang akan membuat surat wasiat, sehingga dapat menjadi Notaris yang amanah dan dapat bermanfaat bagi masyarakat umum.

Akibat hukum terhadap akta wasiat yang dibuat oleh seorang Notaris yang melakukan perbuatan melawan hukum atas kelalaiannya dalam pembuatan akta (isi) adalah hilangnya keotentikan akta tersebut dan menjadi akta di bawah tangan serta akta otentik tersebut dapat dibatalkan apabila pihak yang mendalilkan dapat membuktikannya dalam persidangan di pengadilan, karena pembuatan suatu akta otentik harus memuat unsur lahiriah, formil, dan materiil, atau salah satu unsur tersebut tidak benar dan menimbulkan perkara pidana atau perdata yang kemudian dapat dibuktikan ketidakbenarannya. Sehingga dalam menjalankan tugas jabatannya, Notaris harus tunduk pada ketentuan undangundang dan akta tersebut dibuat oleh dan di hadapan Notaris sesuai dengan prosedur dan tata cara pembuatan akta otentik agar keotentikannya tidak menjadi akta di bawah tangan atau akta tidak sampai dibatalkan.

\section{Daftar Pustaka:}

\section{Buku}

Adjie, Habib, Sanksi Perdata dan Administratif Terhadap Notaris Sebagai Pejabat Publik, Cetakan Kedua, Refika Aditama, Bandung, 2009.

- Sekilas Dunia Notaris \& PPAT Indonesia, Cetakan Pertama, CV. Mandar Maju, Bandung, 2009.

, Hukum Notaris Indonesia; Tafsir Tematik Terhadap Undang-Undang Nomor 30 Tahun 2004 Tentang Jabatan Notaris, Cetakan Keempat, PT. Refika Aditama, Bandung, 2014.

Penafsiran Tematik Hukum Notaris Indonesia Berdasarkan Undang-Undang Nomor 2 Tahun 2014 tentang Perubahan Atas Undang-Undang Nomor 30 Tahun 2004 tentang Jabatan Notaris, Cetakan Pertama, PT. Refika Aditama, Bandung, 2015.

Kebatalan Dan Pembatalan Akta Notaris, Cetakan Ketiga, PT. Refika Aditama, Bandung, 2015.

Ali Boediarto, M., Kompilasi Kaidah Hukum Putusan Mahkamah Agung, Hukum Acara Perdata Setengah Abad, Swa Justitia, Jakarta, 2005.

Ali, Zainuddin, Pelaksanaan Hukum Waris di Indonesia, Sinar Grafika, Jakarta, 2010. 
Algra, N.E., H.R.W. Gokkel, dkk, Kamus Istilah Hukum Fockema Andreae; BelandaIndonesia, Dalam Habib Adjie, Kebatalan Dan Pembatalan Akta Notaris, Cetakan Ketiga, PT. Refika Aditama, Bandung, 2015.

Badudu, Zain, Kamus Umum Bahasa Indonesia, Pustaka Sinar Harapan, Jakarta, 1994.

Bisyri Syakur, Ahmad, Panduan Lengkap Mudah Memahami Hukum Waris Islam Dilengkapi Hibah dan Wasiat, Visimedia Pustaka, Jakarta, 2015.

Budiono, Herfien, Kumpulan Tulisan Hukum Perdata di Bidang Kenotariatan, PT Citra Aditya Bakti, Bandung, 2013.

Efendi Lotulung, Paulus, Perbandingan Hukum Administrasi dan Sistem Peradilan Administrasi, Cetakan Kedua, Citra Aditya Bakti, Bandung, 1993.

Ghofur Anshori, Abdul, Lembaga Kenotariatan Indonesia; Perspektif Hukum dan Etika, Cetakan Pertama, UII Press, Yogyakarta, 2009.

H.R, Ridwan, Hukum Administrasi Negara, Raja Grafindo Persada, Jakarta, 2006.

Indroharto, Usaha Memahami Undang Tentang Pengadilan Tata Usaha Negara, Cetakan Pertama, Pustaka Sinar Harapan, Jakarta, 1996.

Junaidi, Ahmad, Wasiat Wajibah Pergumulan antara Hukum Adat dan Hukum Islam di Indonesia, Pustaka Pelajar, Yogyakarta, 2013.

K. Lubis, Suhrawardi, Hukum Kewarisan Islam, Sinar Grafika, Jakarta, 2013.

Kadir Muhammad, Abdul, Hukum Perusahaan Indonesia, Citra Aditya Bakti, Jakarta, 2010.

Lumban Tobing, G. H. S., Peraturan Jabatan Notaris, Erlangga, Jakarta, 1983.

Luthfan Hadi Darus, M., Hukum Notariat dan Tanggungjawab Jabatan Notaris, Cetakan Pertama, UII Press, Yogyakarta, 2017.

M. Hadjon Philipus, dan Tatiek Sri Djatmiati, Argumentasi Hukum, Gadjah Mada University Press, Yogyakarta, 2005.

M. Situmorang, Victor, dan Cormentyna Sitanggang, Grosse Akta Dalam Pembuktian dan Eksekutorial, Cetakan Pertama, Rineka Cipta, Jakarta, 1993.

Manan, Bagir, Hukum Positif Indonesia, UII Press, Yogyakarta, 2004.

Ngani, Nico, Metode Penelitian Dan Penulisan Hukum, Pustaka Yustisia, Yogyakarta, 2002.

Perangin, Efendi, Hukum Waris, Raja Grafindo, 2001.

Prent, K., Adi Subrata, dan W.J.S. Poerwadarminta, Jakarta, Ensiklopedi Nasional Indonesia, Cetakan Keenam, Kanisius, Yogyakarta, 2001.

Rahmi Ria, Wati, Hukum Waris Islam, Lembaga Penelitian Universitas Lampung, Bandar Lampung, 2011.

Soekanto, Soejono, Pengantar Penelitian Hukum, Universitas Indonesia Press, Jakarta, 2007. , dan Sri Mamudjim, Penelitian Normatif Suatu Tinjauan Singkat, Rajawali Press, Jakarta, 1986. 
Susanto, Herry, Peranan Notaris Dalam Menciptakan Kepatutan Dalam Kontrak, Cetakan Pertama, UII Press, Yogyakarta, 2010.

Syarifin, Pipin, Pengantar Ilmu Hukum, Pustaka Setia, Bandung, 1999.

Tiena Masriani, Yulis, PengantarHukumIndonesia, PT. Sinar Grafika, Jakarta, 2008.

Utrecht, E., Pengantar Hukum Administrasi Negara Indonesia, Cetakan Keenam, Ichtiar, Jakarta, 1999.

Wojowasito, S., Kamus Umum Belanda-Indonesia, Ichtiar Baru-Van Hoeve, Jakarta, 1990.

Zuhaily, Wahbah, Al-Figh al-Islam wa Adillatuhu, Dikutip dari Saifuddin Arief, Notariat Syariah Dalam Praktik, Cetakan Pertama, Darunnajah Publishing, Jakarta, 2011.

\section{Jurnal}

Hartono, Honggo, "Roles of Notary in Drawing Up Marriage Agreement After Constitutional Court Decision Number 69/PUU-XIII/2015", Prophetic Law Review, Vol. 2., No. 2, 2020.

\section{Tesis}

Mireille Titisari Miarti Prastuti, "Peran dan Tanggungjawab Notaris atas Akta Wasiat (Testament Acte) yang Dibuat Dihadapannya", Tesis, Semarang, Magister Kenotariatan Universitas Diponegoro, 2006.

\section{Peraturan Perundang-undangan:}

Kitab Undang-Undang Hukum Perdata.

Kompilasi Hukum Islam.

Undang-Undang Nomor 5 Tahun 1986 tentang Peradilan Tata Usaha Negara.

Undang-Undang Nomor 3 Tahun 2006 tentang Perubahan Atas Undang-Undang Nomor 7 Tahun 1989 tentang Peradilan Agama.

Undang-Undang Nomor 2 Tahun 2014 tentang Perubahan Atas Undang-Undang Nomor 30 Tahun 2004 tentang Jabatan Notaris.

Permenkumham Nomor M.02.PR.08.10 Tahun 2004 tentang Tata Cara Pengangkatan Anggota, Pemberhentian Anggota, Susunan Organisasi, Tata Kerja, dan Tata Cara Pemeriksaan Majelis Pengawas.

Kode Etik Ikatan Notaris Indonesia.

\section{Data Elektronik}

https:/ /wetten.overheid.nl/BWBR0010388/2020-01-01, Akses 19 Januari 2020. http://kerinci.kemenag.go.id, Akses 19 Januari 2020.

https://www.hukumonline.com/berita/baca/lt51e370a2338ed/peran-notarisdalam-kasus-djoko-susilo/, Akses 1 April 2020. 